Symposia Proposals and Abstract Submissions: For TMS-sponsored meetings, symposia proposals and abstracts must be submitted through ProgramMaster, the on-line TMS conference and proceedings management system. The system can be accessed at www.tms.org. Using the Meetings \& Events pulldown menu, select the Upcoming TMS Meeting for which you wish to submit a symposia proposal or an abstract, and follow the on-line instructions. The society especially encourages the submission of "hot-topic" symposia or special-session proposals on timely or developing subjects. To advance an idea, use the symposium creation form in ProgramMaster. Additional information can be acquired from the TMS Technical Support Services Department, 184 Thorn Hill Road, Warrendale, PA 15086; (724) 776-9000, ext. 275; fax (724) 776-3770.

\title{
TMS-Sponsored Events
}

\section{Superalloys 2012}

September 9-13, 2012

Champion, Pennsylvania

The purpose of this Twelfth International Symposium on Superalloys is to provide a forum for researchers, producers, and users to present the most recent technical information on a class of high-strength, high-temperature alloys commonly known as superalloys. The overall scope seeks to highlight advances in superalloys made possible by practical application of modeling and simulation. The technical focus will be on alloy development, processing, coatings and environmental effects, and mechanical behavior, with an increased focus on how modeling tools were developed and applied in these areas. Contact: Meeting Services, TMS, 184 Thorn Hill Road, Warrendale, PA 15086; (724) 776-9000, ext. 243; e-mail mtgserv@tms.org; www.tms.org/Meetings /Specialty/Superalloys2012/home.aspx.

\section{Industrial Aluminum Electrolysis Course}

September 9-14, 2012

Jonquiere, Quebec, Canada

This popular biannual conference will cover a broad range of theoretical and practical applications in aluminum manufacturing, with more than 30 lectures planned on topics such as Alumina Quality and Solubility; Anode Effect Mechanism and Emission Rates; Current Efficiency Improvements and Optimization; Diagnosis of Problem Pots; Electrolyte Compositions; Heat Balance Fundamentals; Optimizing Work Practices to Minimize Disturbances and Maximize Smelter Cell Performance; Productivity \& Work Practice Challenges; Use of Stored Data/Recent History of Cell Condition Variations for Advanced
Diagnostics of Abnormalities; and Work Practices and Safety in Potrooms. A highlight of the program will be a tour of the Rio Tinto Alcan Jonquiere smelter. Contact: Meeting Services, TMS, 184 Thorn Hill Road, Warrendale, PA 15086 USA; (724) 776-9000, ext. 243; fax: (724)776-3770; e-mail: mtgserv@ tms.org; www.tms.org/meetings/2012 /IndustrialAluminumElectrolysis/home. aspx.

\section{MS\&T 2012 \\ October 7-11, 2012 \\ Pittsburgh, Pennsylvania}

The Materials Science \& Technology (MS\&T) partnership of four leading materials societies - ACerS, AIST, ASM, and TMS - brings together scientists, engineers, students, policy makers, suppliers and more to discuss current research and technical applications, and to shape the future of materials science and technology. NACE International will again co-sponsor MS\&T. Ten theme areas will be the focus of this conference. These areas include Biomaterials, Ceramic and Glass Materials, Electronic and Magnetic Materials, Energy Issues, Fundamentals and Characterization, Iron and Steel, Materials - Environment Interactions, Materials Performance, Processing and Product Manufacturing, and Special Topics. Contact: Meeting Services, TMS, 184 Thorn Hill Road, Warrendale, PA 15086; (724) 776-9000, ext. 243; fax: (724) 776-3770; e-mail:mtgserv@tms.org;www .matscitech.org.

\section{TMS2013 \\ March 3-7, 2013 \\ San Antonio, Texas}

The TMS 2013 Annual Meeting \& Exhibition brings together more than 3,800 business leaders, engineers, scientists and other professionals in the materials field for an outstanding exchange of technical knowledge. TMS2013 will also include the symposium REWAS 2013: Enabling Metal Resource Sustainability, which will provide an interdisciplinary and multidisciplinary platform where the materials and metallurgical professional can interact and exchange with other stakeholders and research fields to facilitate the transition to a more sustainable industry and society. By taking a material-focused perspective as well as a product-focused perspective bridges between the two can be forged. Contact: Meeting Services, TMS, 184 Thorn Hill Road, Warrendale, PA 15086; (724) 776-9000, ext. 243; fax: (724) 776-3770; e-mail:mtgserv@tms.org; www .tms.org/meetings/annual-13/AM13home .aspx.

\section{ICME 2013}

July 7-10, 2013

Salt Lake City, Utah

Integrated Computational Materials Engineering (ICME) has received international attention due to its great potential to shorten product and process development time, while lowering cost and improving outcome. Building on the great success of the 1st World Congress on Integrated Computational Materials Engineering in 2011, TMS is launching this conference (ICME 2013) to convene ICME stakeholders-including researchers, educators, and engineers - to examine topics relevant to the global advancement of ICME as an engineering discipline. The goal of ICME 2013 is to assemble the community of ICME contributors to capture the current state of the art, identify current gaps in ICME efforts, and to set the stage for the future growth and application of ICME worldwide. Topics to be covered include foundational engineering problems addressed by an ICME approach; individual computational com- 
ponents of an ICME program; challenges in integrating models to achieve ICME; experimental programs and techniques that support ICME efforts; data management issues, including vetting, sharing, and housing materials data; digital infrastructure required for information sharing and model integration; ICME in engineering education at the undergraduate and graduate level. Contact: Meeting Services, TMS, 184 Thorn Hill Road, Warrendale, PA 15086; (724) 7769000, ext. 243; e-mail mtgserv@tms.org; www.tms.org/meetings/2013/ICME2013 /home.aspx.

\section{PRICM-8}

August 4-9, 2013

Waikoloa, Hawaii

Held every three years, this Pacific Rim International Conference on Advanced Materials and Processing - the 8th in the series of forums dedicated to advanced materials and processing - is being organized this year by TMS. The conference is jointly sponsored by CSM, JIM, $\mathrm{MA}$, and KIM and rotates among these sponsoring organizations. PRICM-8 will include plenary, keynote, and contributed presentations on topics such as advanced high-temperature structural materials; advanced steels and processing; bulk metallic glasses and nanomaterials; composites and hybrid materials; thin films and surface engineering; materials for energy; materials for the environment; rare earth, electronic and magnetic materials; and many others. Abstract submission deadline: December 14, 2012. Contact: Meeting Services, TMS, 184 Thorn Hill Road, Warrendale, PA 15086; (724) 776-9000, ext. 243; fax: (724) 7763770; e-mail: mtgserv@tms.org; www.tms .org/meetings/specialty/pricm8/home.aspx.

\section{TMS Co-sponsored Events}

EWI/TMS Joint Workshop: Applying ICME to Solve Industry's Manufacturing Challenges: September 19-20, 2012, Columbus, Ohio; ewi.org/icme.

Conference of Metallurgists - COM 2012: September 30-October 3, 2012, Niagara, ON, Canada; www.metsoc.org/com2012.asp.

Magnesium Workshop Madrid 2013: May 21-24, 2013, Madrid, Spain; www.tms.org/meetings/2013/MagnesiumWorkshopMadrid/.

\section{General Meetings}

NANOCON 2012: September 19-21, 2012; Brno, Czech Republic; www.nanocon.cz/.

International Conference on Tissue Science and Engineering: October 1-3, 2012; Chicago, llinois; www.omicsonline.org/tissuescience2012.

12th International Symposium on Dendritic Cells: October 7-11, 2012; Daegu, South Korea; www.dc2012.kr/.

Titanium 2012: October 7-10, 2012; Atlanta, Georgia; www.titanium.org.

ebeam 2012 - International Conference on High-Power Electron Beam Technology: October 14-16, 2012; Reno, Nevada; www.vonardenne.biz/ebeam2012.

International Conference and Expo on Material Science \& Engineering: October 22-24, 2012; Chicago, Illinois; www.omicsonline.org/materialscience2012/index.php.

LME 2012 - Lasers for Manufacturing Event: October 22-24, 2012; Schaumburg, Illinois; www.lia.org/conferences/laserevent.

2012 IEEE Nuclear Science Symposium and Medical Imaging Conference: October 29-November 3, 2012; Anaheim, California; www.nss-mic.org/2012.

19th Rolling Conference: November 6-8, 2012; Santa Fe, Argentina; www.siderurgia.org.ar.conf12/.

Cellular Materials - CELLMAT 2012: November 7-9, 2012; Dresden, Germany; www.min-eng.com/processmineralogy 12.

Process Mineralogy '12 - 2nd International Symposium on Process Mineralogy: November 7-9, 2012; Cape Town, South Africa; www.min-eng.com/processmineralogy12/.

Precious Metals '12 - 4th International Symposium on Precious Metals: November 12-13, 2012; Cape Town, South Africa; www.min-eng.com/preciousmetals12.

Met Coke World Summit 2012: November 13-14, 2012; Pittsburgh, Pennsylvania; www.metcokeworldsummit.com/Home.aspx.

CODE 2012: Current and Future Directions in Engineering with Computers: November 13, 2012; Jeju, Korea; www.code2012.org/.

Fatigue and Fracture Metallic Medical Materials and Devices: November 14, 2012; Atlanta, Georgia; cts.vresp.com/c/?ASTMInternational/93acdc7eb3/a16c659475/b7b43920d7.

Processing of Nickel Ores and Concentrates (Nickel Processing '12): November 14-15, 2012; Cape Town, South Africa; www.mini-eng.com/nickelprocessing12.

International Conference and Expo on Material Science and Engineering: November 19-20, 2012; San Antonio, Texas; omicsonline.org/materialscience2012/index.php.

2nd International Conference on Materials Science, Metal \& Manufacturing: November 19-20, 2012, Bali, Indonesia; www.m3-conference.org/.

Procemin 2012: November 21-23, 2012; Santiago, Chile; www.procemin.com/.

12th International Conference on Control, Automation, Robotics and Vision, ICARCV 2012: December 5-7, 2012; Guangzhou, China; www.icarcv.org/.

IEEE International Electron Devices Meeting - IEDM: December 10-12, 2012; San Francisco, California; www.ieee-iedm.org/.

CFD2012: 9th International Conference on CFD in the Minerals and Process Industries: December 10-12, 2012; Melbourne, Australia; www.cfd.com.au/cfdconf/.

ICST 2012 - 8th International Conference on Sensing Technology: December 18-21, 2012; Kolkata, India; seat.massey.ac.nz/conferences/icst2012/.

142nd SME Annual Meeting and Exhibit: February 24-27, 2013; Denver, Colorado; www.smenet.org/meetings.

PDAC 2012 International Convention, Trade Show \& Investors Exchange: March 3-6, 2013; Toronto, Canada; www.pdac.ca/pdac/conv/index.aspx.

Fourth International Conference on Accelerated Carbonation for Environmental and Materials Engineering (ACEME13): April 10-12, 2013; Leuven, Belgium; cit.kuleuven.be/aceme13/.

5th International Conference on Recyrstallization and Grain Growth: May 5-10, 2013; Sydney, Australia; www.rex-gg2013.org/.

Sustainability through Resource Conservation and Recycling '13: May 6-8, 2013; Falmouth, Cornwall, U.K.; www.min-eng-com/srcr13/.

ISRS2013: May 12-17, 2013; Jeju Island, Korea; www.isrs2013.org/.

Aluminum Two Thousand: May 14-18, 2013; Milano, Italy; www.aluminium2000.com/.

Magnesium Workshop Madrid 2013: May 21-24, 2013; Madrid, Spain; www.tms.org/meetings/2013/MagnesiumWorkshopMadrid/.

Computational Modeling '13: June 18-19, 2013; Falmouth, Cornwall, U.K.; www.min-eng.com/modelling13.

Physical Separation '13: June 20-21, 2013; Falmouth, Cornwall, U.K.; www.min-eng.com/physicalseparation13/.

Rapid Excavation and Tunneling Conference - RETC: June 23-26, 2013; Washington, D.C.; www.retc.org.

Multi-Functional Materials and Structures (MFMS 2013): July 14-17, 2013; Bangkok, Thailand; www.kmutt.ac.th/iit/mfms2013.

LCF7 Seventh International Conference on Low Cycle Fatigue: September 9-13, 2013; Aachen, Germany; www.lcf7.de/.

Euro Intelligent Materials: September 25-27, 2013; Kiel, Germany; www.intelligent-materials.de/.

Flotation '13: November 14-18, 2013; Cape Town, South Africa; www.min-eng.com/flotation13/.

Thermec 2013: December 2-6, 2013; Las Vegas, Nevada; www.thermec.org/2013. 